\title{
Teaching issues of contemporary history using historical sources and modern teaching methods
}

\author{
Gabriela Gruber ${ }^{1, *}$ \\ ${ }^{1}$ Lucian Blaga University of Sibiu, Sibiu, Romania
}

\begin{abstract}
The study of history is becoming increasingly less interesting to students, despite the fact that the history teaching process has been continuously modernized during recent years. It is an observation which can be perceived even if we don't make an elaborated research in the field. Some empirical data show us that students in secondary and High Schools are less interested in studying History than in studying Geography or other social sciences. The number of students who are determined to study History in universities has significantly dropped in recent years [1]. Of course, there are multiple causes and the factors behind this change are numerous and varied. In this paper we handle only some changes in teaching History in High Schools, as they are designed in History Curricula and in History textbooks. Therefore during the first sequence of this paper we shall analyze the History Curricula for High School, 11th and 12th grades, regarding their finalities (competencies), some relevant contents and the recommended pedagogical approaches about the teaching methods and the auxiliary material. In the second part of the paper we propose some teaching activities through which students would practice the specific competencies from their Curriculum for History. We aim at presenting attractive teaching material and learning methods and applying the methodological recommendations from the High school Curricula for History, 11 th and 12 th grades.
\end{abstract}

\section{A short analysis on the 11-th and the 12-th grades Curricula for History}

The Romanian education reform has led to major changes in teaching history. School programs have received a curricular structure for all school subjects. Thus, they include an introductory note, general and specific competencies, contents, values and attitudes and methodological suggestions. Competencies are defined as knowledge, abilities and attitudes that are assimilated by students during the years of studying a specific school subject. The general competencies listed in the History Curricula for High School are: the efficient use of specific historical terminology in communication; the practice of democratic approaches and civic actions; the application of the principles and appropriate methods to address

${ }^{*}$ Corresponding author: gabriela.gruber@ulbsibiu.ro 
historical sources and the use of resources that support lifelong learning. [2] The specific competencies are those finalities in studying History to which every student has to arrive from one year of study to another. Thus, the specific competencies are different from one class to another, becoming more complex and more diversified. A comparative presentation of these specific competencies in History study, from the 11th to the 12th grades is presented in the table below:

Table 1. General and Specific competencies from Curricula of History, High School, 11th and 12th grades (High School Curricula for History, 11th and 12th grades, Bucharest, 2009)

\begin{tabular}{|c|c|c|}
\hline \multirow{2}{*}{$\begin{array}{c}\text { General } \\
\text { competencies }\end{array}$} & \multicolumn{2}{|c|}{ Specific competencies } \\
\hline & 11th grade & 12th grade \\
\hline $\begin{array}{l}\text { 1.Efficient use of } \\
\text { specific historical } \\
\text { terminology in } \\
\text { communication; } \\
\text { practicing democratic } \\
\text { approaches and civic } \\
\text { actions }\end{array}$ & $\begin{array}{l}\text { 1.1 Formulating written and oral } \\
\text { opinions on a topic of history; } \\
1.2 \text { Developing an oral or written } \\
\text { argumentation; } \\
1.3 \text { Comparison on different } \\
\text { opinions and arguments } \\
\text { regarding an historical issue. } \\
\text { *1.4 Supporting an argued point } \\
\text { of view in a discussion/ referee } \\
\text { on topics of history }\end{array}$ & $\begin{array}{l}1.1 \text { Building explanations, intra and } \\
\text { multidisciplinary arguments about } \\
\text { historical events and processes; } \\
1.2 \text { Use of terms /concepts specific to } \\
\text { History in contexts involving } \\
\text { interdisciplinary interpretations and } \\
\text { explanations }\end{array}$ \\
\hline $\begin{array}{l}\text { 2.Practicing } \\
\text { democratic } \\
\text { approaches and civic } \\
\text { actions }\end{array}$ & $\begin{array}{l}\text { 2.1 Knowing and practicing the } \\
\text { values of democratic citizenship; } \\
2.2 \text { Analyzing the institutions, } \\
\text { norms and procedures of } \\
\text { governance } \\
2.3 \text { The use of strategies of } \\
\text { negotiation and civic cooperation }\end{array}$ & $\begin{array}{l}\text { 2.1Building analytic approaches } \\
\text { involving economic, social, political or } \\
\text { cultural contexts; } \\
\text { 2.2 Designing cooperative approach to } \\
\text { identify and develop common goals; } \\
\text { 2.3Discovering the permanency in } \\
\text { conducting historical phenomena } \\
\text { 2.4Comparison and assessment of } \\
\text { different reasons to formulate their own } \\
\text { judgments. }\end{array}$ \\
\hline $\begin{array}{l}\text { 3.Applying the } \\
\text { appropriate } \\
\text { principles and } \\
\text { methods to address } \\
\text { historical sources }\end{array}$ & $\begin{array}{l}\text { 3.1 Selecting and commenting } \\
\text { historical sources to } \\
\text { support/combat a point of view } \\
\text { 3.2Comparing the relevance of } \\
\text { historical sources in approaching } \\
\text { a subject } \\
3.3 \text { The discovery of different } \\
\text { perspectives on historical events } \\
\text { and processes in sources of } \\
\text { information }\end{array}$ & $\begin{array}{l}\text { 3.1 Comparison of historical sources to } \\
\text { establish their credibility and validity; } \\
3.2 \text { Analyzing the messages sent by } \\
\text { different historical sources through } \\
\text { comparison the terminology they are } \\
\text { using }\end{array}$ \\
\hline $\begin{array}{l}\text { 4.Using resources } \\
\text { that support lifelong } \\
\text { learning }\end{array}$ & $\begin{array}{l}\text { 4.1 Designing a research with an } \\
\text { historical topic } \\
4.2 \text { Using resources and } \\
\text { technologies of information and } \\
\text { communication to investigate an } \\
\text { historical event or process }\end{array}$ & $\begin{array}{l}\text { 4.1Discovering opportunities in history } \\
\text { research as a source of permanent } \\
\text { learning; } \\
4.2 \text { The integration of knowledge } \\
\text { obtained from non-formal learning } \\
\text { environment in analyzing historical } \\
\text { phenomena; } \\
4.3 \text { Analyzing similar, opposite and } \\
\text { complementary points of view related } \\
\text { with the historical phenomena that are } \\
\text { studied; } \\
4.4 \text { Making connections between } \\
\text { information provided by historical } \\
\text { sources and the context of their daily } \\
\text { life. }\end{array}$ \\
\hline
\end{tabular}


These competencies are related with complex History contents during the 11th and the 12th grades. The Curricula organizes History contents differently from the inferior to the superior curricular cycles of the High School. Thus, the contents are chronologically organized during the 9 th and the 10th grades, but thematically during the 11th and the 12th grades. That means that during the 11th and the 12th classes students have to synthesize their previous knowledge of History and have to approach it from multiple points of view. In order to develop the competencies above, students have to express their opinions sustained with facts, logics and evidences, they have to argument and to compare events and processes. They also have to prove competencies in using technology for information.

The Curricula for History organizes the contents in greater areas, such as "Peoples and historical places", "People, Society and the World of Ideas", "The State and the Politics", "International Relationships" or "Religion and Religious Life". Therefore, the themes are complex, aimed at integrated approaches of History of the world, both that of Europe or the national one. Contents often provide controversial and sensitive topics [3-4]. Some examples for the 11th class curriculum might be "Europe and the World during the 20th century", "The Economy and Society during the Postwar World", "Cooperation and Conflict", or "Religion in the Contemporary World". The 12th grade curriculum for History proposes complex subjects, but this time the focus is on Romanian history, integrated in the European one. "Discoverers of new places and cultures during the 15th and 19th centuries", "Romanian travelers at home and in the World", "Cultural Policies and Romanians abroad", "Redefining the roles of the State from the First World War to Schumann Plan" are some relevant examples. Such organization of the content in studying History in High school has been recently criticized by important representatives of The Romanian scientists, such as Ion Aurel Pop, who appreciated that the curricula for History does not comply with "the specificity (essence) of the discipline, meaning its diachronic and the placement of historical events in space" [5].

Methodological Suggestions end the Curriculum for History for every year of study. They focus on the new role of the student, that of learner through cooperation, or learner in formal and non-formal contexts. A nuanced methodology of using and interpreting historical sources, depending on the formal type of the source, the significance and techniques of applying the "multi-perspective" concept are some of the most important methodological aspects that must be in the attention of a modern teacher of History.

The textbooks for History in High school are not very well adapted to the newest requirements of Curricula for History. The textbooks provide the texts of the lessons and the teaching material that allow modern teaching approaches. But the applying exercises do not explicitly target the competencies provided by the Curricula. No matter what class they were created for, the text books include images, fragments of historical texts/documents, historical maps, statistical tables or charts, chronological landmarks or vocabulary explanations. Since there are alternative textbooks, the contents of the lessons are very different. However, a textbook is an auxiliary material for both teacher and student. The teacher may be creative with his teaching design, by using his own teaching material and methods that enable his students to develop the competencies required by the Curriculum. Students, on the other side, have to "create their own new understandings on the basis of an interaction between what they already know and believe and ideas and knowledge with which they come into contact" [6]. Thus, the constructivist pedagogical paradigm could complete the traditional teaching process and make the learning process more attractive and interactive. Some trends that are common to such a way of teaching, as synthesized by research, could consist of: attention to the individual and respect for students' background, facilitation of group dialogue that explores an element of the domain; planned or unplanned introduction of formal domain knowledge into the conversation through direct 
instruction, reference to text, opportunities for students to change or add to existing beliefs and understandings through engagement in tasks that are structured for this purpose [6].

\section{Constructivist Teaching Activities for Exercising Specific Competencies through Topics of World or of Romanian History}

The considerations above are the basis from which we begin the teaching design of some learning activities that are aimed to be attractive and efficient for students. Our target is that the designed teaching activities involve the students so that they are able to build their own knowledge and achieve the competencies required by their Curriculum for History. The teaching and learning activities are designed for the lesson "The World after 1989", 11th class. The topics which interest us from the lesson concern the most important events during the revolutionary year 1989, the main causes of the revolutions and the principal changes in the world after 1989. The designed teaching activities are aimed to achieve the specific competencies $1.1 ; 2.1 ; 3.2 ; 3.3$ and 4.2 from the table above. As an introduction, the teacher will project for 6 minutes two fragments of the films entitled "The Revolutions of 1989" [7] and "Romanian Revolution 1989. What really happened" [8]. Before starting the projection, the teacher distributes working individual sheets to students, explaining them which are the requirements. While watching the videos students have to note: 1) the events that are described in the clips; 2) the immediate consequences of the revolutions, which they can observe in each situation. When the projection is ended the students are asked to present their answers to the tasks on the cards. They can complete each other if necessary. Through this activity, students prove the specific competence 1.1 (Formulating oral opinions on a topic of history), using discovery as a teaching-learning method.

For the second activity, students are working frontally. They are asked to read silently the document 2 from their History textbook, "About dignity in dictatorial regime" (Michnik, 1997). Then they have to find the link between the content of the document and the topic of the lesson. The expected answer should reveal that the violation of individuals dignity, violence, torture and terror were the most important causes of the 1989 uprisings against dictatorial regimes in Eastern Europe. The teaching methods that are used in this case are conversation and debate and by interpreting this text students are practicing the competence 2.1 from their Curriculum for History, (knowing and practicing the values of democratic citizenship).

To discuss the main changes that have occurred into the world after 1989, the class will be divided into four groups. Each group will receive a working sheet with different images and information. Students from each group have to answer to the following tasks: Group 1 receives a sheet that contains a map with the former Soviet states and information about the Baltic States and about the Eastern European ones; Group 2 receives the same map, but information about Transcaucasian Republics and about The Central Asian States. The two groups have to identify and to locate the groups of states that they hold information about on the map and exchange information about their population and their about religions. Group 3 receives the map of the former Yugoslavian states and a text entitled "Sloboda Milosevici's Radical Opportunism" (Tismaneanu, Daily, March, 31, 2006). The students in that group have to identify factors that led to the disintegration of Yugoslavia and locate the new states formed after the war in these territories. During discussions students have to understand and use specific terms such as "mafia group", "extreme nationalism", "hegemonic party", which they come into contact with during their lecture. Group 4 receives a fragment of the text "The Century of Extremes" (E. Hobsbawn). The working tasks for the students in this group are: to explain the significance of the apartheid policy in South Africa, as they can understand it from the analyzed text (unlimited power of a minority over a majority); to argument the failure of the apartheid policy and use the ideas 
from the text in their argumentation (the brutality of the governors, ignorance of the political levers of Government, the lack of legitimacy of the political regime). After the groups have presented their answers, students are asked to compare the sources that they have analyzed and appreciate which one is the most relevant in studying the changes in the world after 1989. They have also to argument their selection. By fulfilling these tasks students are practicing the specific competencies 3.1 and 3.2 from their Curriculum for History. Thus, they comment historical sources to support/combat a point of view (3.1) and compare the relevance of historical sources in approaching a subject (3.2). Through these activities students use discovery, group-working and debate as teaching and learning methods and contribute at constructing their knowledge.

The learning activities for the 12th class are centered around the lesson titled "Building the Post revolutionary (Romanian) Democracy". The issues of the lesson which we design teaching activities for refer to: political parties and political groups appeared in Romania during the year 1990; new principles in organizing the State; conflict relationships between political parties and groups in Romania after 1989 and features of the Romanian democracy during transition. As an introduction, students are asked to read the chronological landmarks from their textbooks. Then the teacher distributes working sheets extracted from the Decree-Law No 8/31.12.1989, concerning the legalization of a multiparty political system. The tasks written on these cards are: to identify the political group that has signed the analyzed Decree-Law; to name the principle that has been set at the basis of this document. During this activity students are working individually and aim to achieve the competence 2.1 from the 12th class Curriculum for History, (building analytic approaches involving economic, social, political or cultural contexts). Thus, students discover that the Decree- Law was signed by The Front of National Salvation (FSN) which was the political group that had taken power. They also find out that the document legalized the principle of political pluralism.

The next activity is meant to help students to find out or renew their knowledge about the relationships between political parties born in Romania during 1990. The teacher organizes the class into four groups and gives them working sheets containing information about the result of the Romanian elections in May 1990. Then, a short fragment from the film "23 years from the First Elections Held after 1989 Revolution" [9] (in Romania) is projected by the teacher. Students are asked to establish which were the political parties and groups participating in the 1990 elections. Watching the film and using the information on their sheets, students are expected to show that Ion Iliescu, the candidate of the Front of National Salvation won the elections, while Radu Campeanu (NLP) and Ion Ratiu (NPPCD) lost them. The main political parties that students could identify from their working sheets are FSN (The Front of National Salvation), UDMR (Democratic Union of Hungarians in Romania), PNȚCD (The National Peasant Party Christian and Democratic), PSDR (The Social Democratic Party in Romania), etc. Students are also asked to discuss in their groups and argument economically, politically or culturally to explain the outcomes. To do this, students have to use specific historical terms in contexts involving interdisciplinary approaches. Thus, they achieve the specific competencies 1.2 and 2.1 from their Curriculum for History.

The characteristics of the Romanian democracy during the years of transition are discussed during the next teaching activity. Students receive working sheets with two texts to be analyzed. The first text contains a fragment from the "Proclamation in Timisoara", point eight, calling for prohibition of the former communist leaders or former Security officers to participate in public life. The second text represents a short fragment written by Timothy Garthon Ash in his "Truth about the revolutions in 1989", published in 1999. The text on students" sheet defines the "civil society" as "organizations which aren't controlled by parties or by a State party". The class is divided into groups of four that have to choose 
the text which they will analyze during the next minutes. Organized in pairs, students in each group have to write 4 minutes for and against depositions about the justice of the eight point of Proclamation in Timișoara, or about the necessity of the civil society in Romania after 1989. After 4 minutes, pairs split up, seeking for a fellow from another pair in the classroom with the same type of arguments and the same analyzed document. The new pairs work together for another 5 minutes and share their arguments. Then, the initial pairs reunite and bring their enriched arguments into the initial groups. For six minutes the two pairs in the group debate their problem based on the opposite arguments which they have produced by cooperation. Thus, students practice the 4.3 specific competence from their Curriculum for History (Analyzing similar, opposite and complementary points of view related with the historical phenomena that are studied), learning by cooperation and using the so called academic controversy as a teaching and learning method.

The last teaching activity proposed by this paper occurs with the so called phenomenon of "Miners", which took part in Romania during 1990. The Romanian society was dividing into two groups: those who wanted a major change in the governance policy towards a real democracy and those who wanted to maintain the power of the survivors of the communist regime. The miners, a group of professionals from the mining Romanian counties came to Bucharest to "restore order" or to spread the ones who protested peacefully in the University Square. Violence resulted in deaths and injuries. The teaching activity which we are proposing is aimed at making students practice the specific competences 2.4 and 3.1 from the 12th grade Curriculum for History (Comparison and assessment of different reasons to formulate their own judgment and Comparison of historical sources to establish their credibility and validity). For this activity, the teacher prepares four texts with different opinions of the participants at the events in Bucharest in the June 1990. The first text represents the views of a man in the street who was aggressed by two miners, was hit in the face and fell down, losing his consciousness. The second text represents the opinion of a miner who participated in the events. He declares that there were drugs on the street, without knowing for sure how the drugs looks like. The third text represents a declaration of Miron Cozma, the miners` leader, who said that he was called "by someone important at Cotroceni" and was asked to go to Bucharest. Miron Cozma also said that he was expected by Gelu Voican-Voiculescu, the vice-president of the Government of that time, whom he had a discussion with. The fourth text presents a fragment from an article in the Romanian journal, "The Truth". The author describes a violent scene in the Police headquarter in Bucharest. Into a fire burned decor, the author presents some miners' victims, describing them as individuals full of blood, drugged and hysterical. Each of the four groups of students receives a sheet that contains two of the four texts, differently combined. The different combination of the texts is meant to allow groups to make various comparisons between the perspectives of the stakeholders, but also between the credibility of the sources. The working tasks are the same for all the groups:1) to compare the opinions related by the documents and appreciate the credibility of the sources; 2) to sustain their points of view, based on the ideas expressed by sources but also on the author's role in the events that they are describing. These activities cover only parts of the contents of the cited lessons. We chose to design these teaching activities as examples of possible good practices in achieving the requirements of the Curricula for History by valorizing interesting teaching material and modern teaching methods.

\section{Conclusion}

The reform in the Romanian education determined important changes in the Didactics of History. The disciplinary competencies, the new approaches of the contents assimilated by students, the new methods and teaching material allow the teacher of History to be creative 
in designing his teaching activities. Some aspects of teaching History in High schools supported major criticism from specialists in History. The value of some competencies from the Curricula for History is criticized, contents are sometimes poorly organized, the textbooks are old or too crowded with information. The textbooks may have few teaching materials, which are not always the most compatible with the competencies required by the Curricula for History. However, a careful teaching design, a proper interpretation of the different aspects of the contents and a judicious correlation between the contents and the competencies lead to attractive teaching activities, correctly oriented towards the competencies in History and towards the correct historical contents. Students learn by cooperation, they can use information assimilated from non-formal learning and build their knowledge together. But they need well selected teaching material, modern and active learning scenarios which can be designed and realized by modern and interested teachers, with effort and creativity.

\section{References}

1. Ministry of National Education and Scientific Research, Report on the status of Higher Education in Romania, accessed 21.02.2017 https:/www.edu.ro/sites/default/ files/Raport\%20Stare\%20invatamant\%20superior\%202015.pdf (Bucharest, 2015)

2. Ministry of Education, Research and Innovation, School Curricula. History, 12th grade, http://www.isjcta.ro/wp-content/uploads/2013/06/istorie_12.pdf., accessed 21.02. 2017

3. R. Stradling, Teaching the XXth Century History, (Corint, 2003, 87)

4. S.P. Bolovan, Teaching History (Presa Universitara Clujeana, 2007, 85)

5. F. Pop, Do we need History in Schools? The Truth, accessed 20.02.2017 from http://adevarul. ro/locale/cluj-napoca/de-nevoie-istorie-scolil-rectorul-ubb-la-tara-matematicafizica-chimie-nuinteleg-profesorii-ceea-predau-daramite-elevii-1_56c741bf5ab6550cb8fc302f/index.html (2016)

6. V. Richardson, Constructivist Pedagogy, in TCR 105(9), 1623-1626, (2003)

7. https://www.youtube.com/watch? $=$ hc2XGHA7NK4, accessed 24.02.2017

8. https://www.youtube.com/watch?v=VeXJevm1cQc, accessed 24.02.2017

9. http://stiri.tvr.ro/23-de-ani-la-primele-alegeri-libere-desfasurate-dupa-revolutia-din-decembrie1989 30707.html, accessed 25.02.2017 